\title{
PEMANFAATAN DISKRESI KEWENANGAN PEMUNGUTAN DAN PENAGIHAN PAJAK DI MASA PANDEMI COVID-19
}

\author{
F.C. Susila Adiyanta \\ Fakultas Hukum, Universitas Diponegoro, Semarang \\ e-mail: fcsusilaadiyanta@lecturer.undip.ac.id; susilaadiyanta@gmail.com \\ C. Sri Widyastuti \\ Program Magister Manajemen, Universitas Diponegoro, Semarang \\ e-mail: catharinaeswe@gmail.com \\ Evi Rosalina \\ Fakultas Hukum, Universitas Diponegoro, Semarang \\ e-mail: evirosalina@gmail.com
}

\begin{abstract}
ABSTRAK
Dasar pertimbangan pemerintah dalam menggunakan diskresi kewenangan pajak di masa pandemi Covid-19 menggunakan metode pendekatan doktrinal. Berbagai bauran kebijakan Pemerintah berupa berbagai produk hukum Peraturan Menteri Keuangan di bidang perpajakan yang pelaksanaannya dilakukan oleh Pemerintah Direktorat Jenderal Pajak merupakan bentuk penggunaan diskresi kewenangan dalam pemungutan dan penagihan pajak, berdasarkan pada pertimbangan untuk tujuan menyelamatkan penerimaan negara dari sektor pajak dengan tetap tunduk pada norma hukum positif yang berlaku. Fleksibilitas penggunaan diskresi kewenangan untuk pemungutan dan penagihan pajak pada masa pandemi Covid-19, diantaranya digunakan untuk memfasilitasi program perlindungan sosial dan kesehatan masyarakat, mengalokasikan dana stimulus dan relaksasi fiskal secara lebih merata. Rekomendasi dari hasil penelitian yuridis normatif ini adalah: Pemerintah hendaknya tetap mempertimbangkan prinsip ability to pay dan membuat kebijakan perluasan basis pajak dalam memungut dan melakukan penagihan pajak; Pemerintah perlu mempertimbangkan berbagai kebijakan insentif pajak dan memfasilitasi kemudahan administrasi perpajakan dengan tarif pajak yang kompetitif bagi investor yang mendukung pertumbuhan iklim ekonomi.
\end{abstract}

Kata Kunci: Penagihan Pajak; Diskresi Kewenangan; Valuasi Yuridis; Pandemi Covid-19

\section{ABSTRACT}

The basis for the government's consideration in using discretionary tax authority during the Covid-19 pandemic uses a doctrinal approach. Various government policy mixes in the form of various legal products of the Minister of Finance Regulation in the field of taxation which are implemented by the Government of the Directorate General of Taxes are a form of discretion of power in tax collection and collection, based on considerations for the purpose of saving state revenue from the tax sector by remain subject to the prevailing positive legal norms. Flexibility in using discretionary authority for tax collection and collection during the Covid-19 pandemic, including being used to facilitate social protection and public health programs, allocating stimulus funds and fiscal relaxation more equitably. Recommendations from this normative juridical research are: The government should considers the principle of ability to pay and makes policies on expanding the tax base in collecting and collecting taxes; The government needs to consider various tax incentive policies and facilitate ease of tax administration with competitive tax rates for investors that support economic growth.

Keywords: Tax Collection; Discretion of Power; Judicial Valuation; Covid-19 Pandemic 


\section{PENDAHULUAN}

Sejak pandemi virus Covid-19 melanda seluruh dunia, semua negara terimbas dampak di segala sektor kehidupan secara sosial, ekonomi, dan politik. Situasi dan kondisi pandemi yang begitu cepat ini menyebabkan hampir semua negara di dunia mengalami resesi ekonomi. Pandemi dan akibatnya yang tidak terduga ini, menuntut reaksi cepat dan masif di seluruh dunia.

Dengan penguasaan sumber daya dan kapasitas untuk memobilisasi manusia, negara memiliki kemampuan untuk mengatasi pandemi. Negara menjadi tumpuan harapan masyarakat untuk menggerakkan ekonomi ketika swasta tidak berani mengambil risiko dan masyarakat yang terbebani sudah tidak dapat lagi menanggung ongkos ekonomi sebagai akibat dari adanya pembatasan gerak dan aktivitas sosial.

Pemerintah negara-negara yang terdampak pandemi menyediakan berbagai paket bantuan ekonomi yang bernilai fantastis untuk mengatasi pandemi. Pemerintah Jerman mengalokasikan dana untuk stimulus ekonomi senilai Euro 650 miliar, Amerika serikat menyediakan paket stimulus sebesar US\$ 2 triliun, terbesar sepanjang sejarah Amerika Serikat (BBC News, 30/03/2020). Begitu pula dengan Pemerintah Indonesia, telah menyediakan paket bantuan sosial dan stimulus ekonomi. Indonesia pada awalnya mengalokasikan dana untuk paket stimulus fiskal pertama dan kedua sebesar Rp 33,2 triliun (setara $0,2 \%$ PDB), terakhir diberikan tambahan sehingga menjadi Rp 405,1 triliun. ${ }^{1}$

Pos anggaran terbesar yang ditetapkan Pemerintah untuk mengantisipasi dampak pandemi Covid-19, sejumlah Rp 150 triliun, dianggarkan untuk kegiatan terprogram bertujuan pemulihan ekonomi nasional berupa restrukturisasi kredit dan pembiayaan bagi pelaku usaha terutama UMKM. Menyusul peringkat jumlah penganggaran terbesar kedua, yaitu Rp 110 triliun, dicadangkan sebagai dana kegiatan perlindungan sosial, yang meliputi program bantuan tunai untuk 10 juta keluarga, bantuan sembako untuk masyarakat sebanyak 20 juta, kartu pra kerja untuk 5,6 juta warga masyarakat yang menjadi korban PHK,

\footnotetext{
${ }^{1}$ Harian Kompas, 21 Maret 2020 dan Laporan Kementerian Keuangan Republik Indonesia dalam Rapat Dengar Pendapa tdengan Dewan Perwakilan Rakyat Republik Indonesia pada tanggal 20 Maret 2020.
}

pembebasan dan subsidi biaya listrik untuk 31 juta pelanggan. Alokasi prioritas anggaran berikutnya adalah bidang kesehatan yang jumlahnya sebesar Rp 75 triliun. Besaran anggaran bidang kesehatan tersebut dialokasikan untuk pengadaan alat kesehatan dan insentif tenaga medis. Pemerintah juga mengalokasikan anggaran untuk insentif pajak dan kredit usaha sebesar Rp 70,1 triliun. ${ }^{2}$

Keputusan berupa penetapan alokasi anggaran fiskal oleh Pemerintah sebagai dukungan dan pemulihan sosial ekonomi untuk mengantisipasi dampak pandemi global Covid-19 ini merupakan langkah yang berani, mengingat alokasi anggaran ini mengubah secara signifikan rencana anggaran pemerintah dalam APBN yang sudah direncanakan dan ditetapkan sebelumnya.

Banyak negara memerlukan dana untuk mengatasi berbagai dampak yang timbul akibat pandemi Covid-19. Selama ini, salah satu tumpuan pemerintah untuk penerimaan anggaran negara berasal dari pajak-pajak yang dipungut dari masyarakat. Di tengah ancaman resesi ekonomi, pengenaan beban pajak kepada masyarakat merupakan kebijakan yang dilematis. Negara membutuhkan dukungan dana yang bersumber dari pajak yang dipungut dari masyarakat, namun pada sisi lain justru masyarakat yang terdampak pandemi memerlukan bantuan dan dukungan finansial dari negara.

Dalam keadaan yang tidak normal atau tidak biasa (extra ordinary condition) seperti wabah pandemi global Covid-19 saat ini, pemerintah memerlukan pengaturan yang bersifat tersendiri dalam penyelenggaraan pemerintahan, sehingga fungsi-fungsi negara dapat terus bekerja secara efektif. Di bidang perpajakan, Pemerintah melalui Kementerian Keuangan RI, diantaranya menerbitkan Peraturan Menteri Keuangan (PMK) Nomor 23/ PMK.03/2020 tentang Insentif Pajak untuk Wajib Pajak Terdampak Wabah Virus Corona, PMK Nomor 19/PMK.07/2020 Penyaluran dan Penggunaan DBH, DAU, dan Dana Insentif Daerah Tahun Anggaran 2020 dalam Rangka Penanggulangan Corona Virus Disease 2019 (COVID-19), PMK Nomor 28/ PMK.03/2020 Pemberian Fasilitas Pajak Terhadap Barang dan Jasa Yang Diperlukan Dalam Rangka Penanganan Pandemi, PMK Nomor 34/PMK.04/2020

\footnotetext{
${ }^{2}$ loc.cit.
} 
tentang Relaksasi Ketentuan Impor Alat Kesehatan untuk Keperluan Penanganan COVID-19 berupa pembebasan dari kewajiban izin edar atau Special Access Scheme (SAS), PMK Nomor 44/PMK.03/2020 tentang Insentif Pajak untuk Wajib Pajak Terdampak Pandemi Corona Virus Disease 2019 serta berbagai bauran kebijakan Pemerintah yang bertujuan untuk optimalisasi untuk menangani pandemi Covid-19 serta menjaga kesinambungan perekonomian.

\section{PERUMUSAN MASALAH}

Berangkat dari realitas sebagaimana dijelaskan pada latar belakang penelitian, maka rumusan masalah penelitian ini adalah mengenai bagaimana dasar pertimbangan diskresi kewenangan fiskus dan fleksibilitas penggunaan diskresi kewenangan pemungutan dan penagihan pajak sebagai sumber penerimaan negara untuk mengantisipasi dampak yang timbul akibat pandemi Covid-19.

\section{METODE PENELITIAN}

Penelitian ini adalah penelitian hukum (legal research) dengan menggunakan pendekatan statuta/ peraturan perundangan-undangan yang ditunjang bahan-bahan hukum dan data empiris. Pada penelitian ini, hukum diidentifikasi sebagai substansi kekuatan sosial maupun struktur institusi pembuat keputusan inconcreto yang berkekuasaan, ${ }^{3}$ yaitu: Pemerintah, Menteri Keuangan, dan Direktorat Jenderal Pajak sebagai presentasi badan eksekutif/jabatan administrasi negara (administratieve bestuur) yang mempunyai otoritas kekuasaan dan kewenangan penggunaan diskresi untuk pemungutan dan penagihan pajak.

\section{PEMBAHASAN}

Dasar Pertimbangan Penggunaan Diskresi Kewenangan untuk Pemungutan dan Penagihan Pajak

Negara dalam mewujudkan kesejahteraan umum memerlukan sarana dan biaya yang diantaranya diperoleh dari pajak yang dipungut dari masyarakat. Dalam konteks negara modern, pajak adalah salah satu bentuk partisipasi serta kewajiban sukarela masyarakat dalam bernegara. Melalui

\footnotetext{
${ }^{3}$ Soetandyo Wignjosoebroto. (2002). Hukum, Paradigma, Metode, dan Dinamika Masalahnya, Jakarta: Penerbit Elsam, h. 178.
}

penerimaan yang diperoleh dari pajak, negara dapat melangsungkan kegiatan pembangunan yang bertujuan untuk meningkatkan kesejahteraan dan kemakmuran seluruh rakyat. Pajak menjadi tulang punggung penerimaan negara, karena pendapatan dari pajak berbanding lurus dengan tingkat pertambahan penduduk, peningkatan ekonomi, dan kondusifitas politik suatu negara.

Sebagai suatu negara yang berdasarkan hukum, sumber hukum formal pemungutan pajak di Indonesia adalah Pasal 23 A UUD 1945 perubahan (amandemen) ke empat, yang secara eksplisit menyatakan bahwa pajak dan pungutan lain yang bersifat memaksa untuk keperluan negara diatur dengan undang-undang. Pernyataan Konstitusi yang menempatkan dasar hukum pemungutan pajak dalam bentuk undang-undang, mengandung arti undangundang pajak yang menjadi dasar kewenangan pemerintah untuk memungut pajak menjunjung asas kerakyatan atau demokrasi dan prinsip negara hukum. Demikian pula bahwa persetujuan untuk membuat undang-undang perpajakan (melalui wakil-wakilnya di DPR) merupakan dasar legitimasi pemungutan pajak kepada rakyat.

Negara Indonesia, menurut UUD 1945 secara eksplisit menganut paham negara kesejahteraan atau dikenal sebagai paham big state, adalah paham tentang negara sebagai penyelenggara kesejahteraan publik yang bertanggungjawab atas distribusi ekonomi dan pemerataan pembangunan. Paham negara big state ini juga dinyatakan dalam Konstitusi Negara Indonesia. Merealisasikan kesejahteraan sosial merupakan amanat yang diberikan oleh UUD 1945 kepada negara, merupakan tugas khusus yang diemban badan administrasi negara - pemerintah sebagai badan eksekutif- di lapangan penyelenggaraan kepentingan umum (public service). ${ }^{4}$ Dalam praktek ketatanegaraan di Indonesia, kewenangan dalam melakukan pemungutan dan penagihan pajak diatur menurut ketentuan Undang-Undang Perpajakan. ${ }^{5}$

\footnotetext{
${ }^{4}$ Sjachran Basah. (1986). Perlindungan Hukum terhadap Sikap Tindak Administrasi Negara. Orasi Dies Natalis XXIX Unpad tgl. 24 September 1986, h. 2 .

5 Pasal 1 Angka 9 UU PPSP: "Penagihan pajak adalah serangkaian tindakan agar penanggung pajak melunasi utang pajak dan biaya penagihan pajak dengan menegur atau memperingatkan, melaksanakan penagihan seketika dan sekaligus, memberitahukan Surat Paksa, mengusulkan pencegahan, melaksanakan penyitaan, melaksanakan penyanderaan, menjual barang yang telah disita."
} 
Negara melalui pemerintah sebagai badan eksekutif berdasarkan undang-undang dapat melakukan pemungutan dan penagihan pajak sebagai bentuk penegakan hukum. Penagihan utang pajak dapat dilakukan terhadap wajib pajak/penanggung pajak, jika tidak mematuhi kewajiban perpajakannya sehingga mempunyai utang pajak yang tidak dibayar sesuai dengan tenggang waktu yang telah ditentukan oleh undang-undang.

Pemerintah dalam menetapkan suatu keputusan berdasarkan kewenangan diskresi (discretion of power, freiesermessen) dalam pemungutan, penagihan pajak sebagai bentuk penegakan hukum pajak yang didasarkan pada pertimbangan manfaat dan kegunaannya bagi kepentingan umum, yaitu manfaat yang sebesar-besarnya dibandingkan dengan kebijaksanaan atau alternatif tindakan lain, dengan tetap berdasarkan norma hukum positif sebagai landasan hukumnya. Dengan lain perkataan, jika yang dipertimbangkan adalah masalah konsekuensi baik dan konsekuensi buruk atas suatu kebijaksanaan atau tindakan, maka penilaian kebijaksanaan atau tindakan adalah baik secara moral jika mampu memberi manfaat yang lebih besar dari kerugian yang ditimbulkannya. ${ }^{6}$

Direktur Jenderal Pajak (selanjutnya disingkat DJP) yang memperoleh otoritas dari pemerintah di bidang perpajakan dapat menggunakan kewenangan diskresi (discretion of power, freiesermessen), yaitu kebebasan bertindak untuk melakukan pemungutan dan penagihan pajak, sebagai bentuk penegakan hukum pajak, baik secara preventif maupun koersif (coercive) untuk menyelamatkan penerimaan negara dari sektor pajak. Penggunaan kebebasan bertindak (freiesermessen) oleh Pemerintah untuk melakukan pemungutan dan penagihan pajak, menurut pandangan utilitarianisme harus mempertimbangkan berbagai aspek yang berkaitan dengan manfaat dan kegunaannya bagi penyelenggaraan pelayanan umum (public service).

Dari persektif paham utilitarian, suatu kebijaksanaan sosial, politik, ekonomi, dan hukum, dinilai baik atau buruk tergantung pada manfaat serta kegunaan dari kebijakan yang dibuat dan ditetapkan pemerintah. Pada kondisi tertentu, saat kerugian

${ }^{6}$ E. Sumaryono. (2020). Etika dan Hukum, Relevansi Teori Hukum Kodrat Thomas Aquinas. Yogyakarta: Penerbit Kanisius, h. 202. tak terhindarkan, maka tindakan yang baik adalah tindakan dengan konsekuensi kerugian terkecil. Jeremy Bentham menyatakan lebih lanjut bahwa asas utilitas menetapkan dasar pemerintahan sipil. Tugas lembaga legislatif adalah memberlakukan hukum yang dapat mempromosikan kebahagiaan sebesarbesarnya bagi sebagian besar orang. Keadilan atau kebenaran hukum hanya dapat ditentukan oleh akibatakibat yang ditimbulkan dalam keberlakuannya. Berdasarkan asas utilitas ini, seorang kepala negara harus selalu mengarahkan segala urusannya sedemikian rupa, sehingga dapat menghasilkan kebahagiaan setinggi-tingginya bagi sebagian besar warga negaranya. ${ }^{7}$

\section{Fleksibilitas Penggunaan Diskresi Kewenangan Pemungutan dan Penagihan Pajak untuk Mengantisipasi Dampak yang Timbul Akibat Pandemi Covid-19}

Pemerintah sebagai penyelenggara pelayanan publik mempunyai peran yang penting dan tanggung jawab luas dalam mengalokasikan serta mendistribusikan setiap dana yang diperoleh dari sektor pajak bagi terlaksananya pembangunan saranasarana publik, penyelenggaraan pelayanan publik, secara merata dan adil bagi kesejahteraan masyarakat. Untuk mewujudkan kesejahteraan umum (bonum publicum), negara memerlukan sarana dan biaya yang diantaranya diperoleh dari pajak yang dipungut dari masyarakat. ${ }^{8}$

Kewenangan pemungutan pajak yang dilaksanakan oleh Pemerintah secara mendasar merupakan fungsi esensial yang digunakan sebagai motor untuk menggerakkan program pembangunan, karena pajak merupakan salah satu penopang utama bagi fungsi penerimaan negara (budgetair), fungsi mengatur (regulerend), maupun stabilitasi ekonomi nasional. ${ }^{9}$ Pemerintah berdasarkan diskresi kewenangan yang diberikan oleh undang-undang dapat menetapkan kebijakan penegakan hukum

\footnotetext{
${ }^{7}$ Hari Chand. (1994). Modern Jurisprudenc. Kuala Lumpur: International Law Book Series, h. 67-70.

${ }^{8}$ Sonny Keraf. (2016). Pasar Bebas, Keadilan, dan Peran Pemerintah. Yogyakarta: Penerbit Kanisius, h. 175-178.

${ }^{9}$ Undang-Undang No. 19 Tahun 1997 tentang Penagihan Pajak dengan Surat Paksa sebagaimana telah diubah dengan Undang-Undang No. 19 Tahun 2000 tentang Perubahan atas Undang-Undang Nomor 19 Tahun 1997 tentang Penagihan Pajak dengan Surat Paksa.
} 
dengan fleksibilitas yang berbasis pada kepentingan umum dan keadilan. Penggunaan diskresi kewenangan untuk pemungutan dan penagihan pajak oleh pemerintah dengan batasan dan ruang lingkup pertimbangan untuk tujuan kepentingan umum, dapat memberi solusi atas permasalahan masyarakat yang timbul secara spontan. ${ }^{10}$

Pada masa pandemi Covid-19, negara memerlukan biaya yang besar untuk mendanai semua keperluannya. Pemenuhan kesejahteraan umum dapat tercapai dengan adanya warga masyarakat yang berperan aktif dalam pemberian kontribusi kepada negara berupa pajak. Pemenuhan kewajiban pajak merupakan salah satu bentuk gotong royong yang sudah lama hidup dalam masyarakat Indonesia. Pemenuhan kewajiban pajak harus tetap dilaksanakan oleh masyarakat wajib pajak. Pemungutan dan penagihan pajak oleh Pemerintah dapat dibenarkan, karena pembayaran pajak merupakan salah satu kewajiban kenegaraan berdasarkan kesepakatan yang telah dirumuskan oleh konstitusi. ${ }^{11}$

Kepatuhan masyarakat Indonesia terhadap pajak tidak mengalami peningkatan yang cukup signifikan. Direktorat Jenderal Pajak Republik Indonesia mengungkapkan bahwa pada tahun 2019 tax ratio, perbandingan pajak terhadap Produk Domestik Bruto (PDB) Indonesia sebesar 10,7\%. Angka tersebut lebih rendah dari tahun 2018 yakni 11,5\%. Tax ratio perpajakan Indonesia ini terbilang amat kecil dibanding tax ratio rata-rata lower midle income country yang sebesar $17,7 \%$. Tax ratio Indonesia sedikit unggul dari Kamboja dan Philipina yang memiliki tax ratio $13,1 \%$. Sedangkan negara-negara seperti Malaysia, Vietnam, dan Thailand mempunyai tax ratio berturut-turut $18,5 \%, 15,3 \%$ dan $14,5 \% .^{12}$

Rendahnya rasio kepatuhan pajak wajib pajak mempunyai korelasi yang signifikan dengan

\footnotetext{
${ }^{10}$ Sjachran Basah. op.cit., h. 9.

${ }^{11}$ Frans Magnis Soeseno. (2006). Etika Politik, PrinsipPrinsip Moral Dasar Kenegaraan Modern. Jakarta: Pustaka Gramedia, h. 98.

12 Direktorat Potensi dan Sistem Perpajakan Direktorat Jenderal Pajak RI dan Data Asian Development Bank (ADB). (2017). Key Indicators of Developing Asian and Pacific Countries, h. 127-128.
}

penerimaan negara di sektor pajak. ${ }^{13}$ Betapa rasio pajak berkolerasi dengan penerimaan dari sektor pajak dapat dilihat dari pemasukan pajak tahun 2019 yang menembus angka Rp1.332 triliun, setara dengan 84,44\% nominal target APBN 2019 yakni Rp1.577,56 triliun. Tingkat pertambahan penerimaan $1,43 \%$, lebih rendah dibandingkan laju pertumbuhan pada rentang waktu yang sama di tahun sebelumnya yang mencapai $14,10 \%$. Tercatat berbagai macam pajak utama mengalami penurunan pertumbuhan, artinya masih mampu tumbuh tetapi dengan besaran persentase lebih rendah dari pertumbuhan tahun 2018, sebagai contoh PPh Pasal 21 pertumbuhannya 10,17\%, sedangkan PPh Pasal 25/29 Badan hanya meningkat $1,07 \%$, sementara PPN Dalam Negeri membukukan angka 3,71\%. Selain itu, beberapa jenis pajak utama bahkan mengalami penurunan atau pertumbuhan negatif, misalnya PPN Impor tumbuh $-8,13 \%$, dan PPh 22 Impor mengalami pertumbuhan $-1,94 \%$, serta PPh 26 juga tumbuh negatif yaitu $-6,65 \% .^{14}$

\section{Infografik 1. Pertumbuhan per jenis Pajak Periode Tahun 2018 dan 2019 (YoY, \%)}

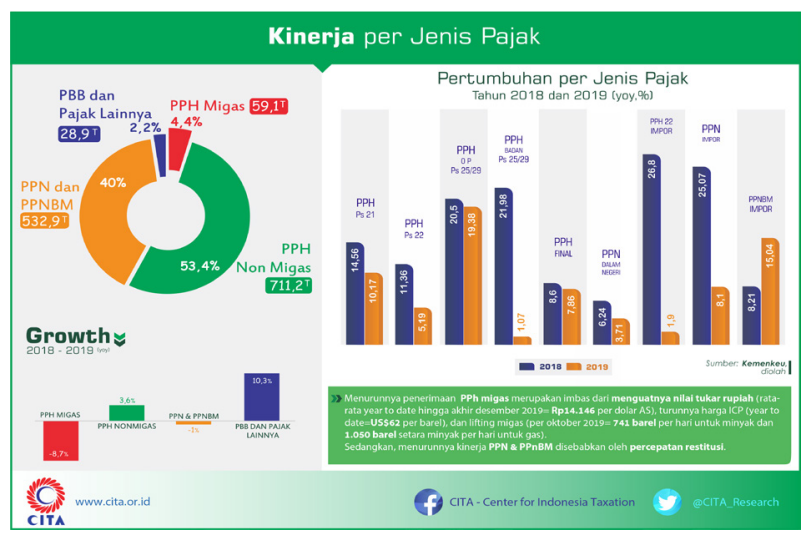

Sumber Data: Disalin dari Center for Indonesia Taxation Analysis dan Diolah dari Laporan Kinerja Direktorat Jenderal Pajak Republik Indonesia (LAKIN DJP RI 2019)

13 Organization for Economic Cooperation and Development (OECD) tahun 2019, dalam publikasi bertajuk "Revenue Statistics in Asian and Pacific Economies 2019", menyatakan bahwa tax ratio Indonesia tahun 2017 adalah 11,5\%, di bawah rata-rata dari negara anggota $\mathrm{OECD}(34,2 \%)$ dengan selisih sebesar 22,7\%, dan juga di bawah rata-rata kawasan LAC (Latin America and the Caribbean) dan Afrika (masing-masing sebesar 22,8\% dan 18,2\%). Rilis Tax Ratio Indonesia oleh OECD dengan menggunakan data periode tahun 2017.

${ }^{14}$ Laporan Kinerja Direktorat Jenderal Pajak Republik Indonesia (LAKIN DJP RI 2019), h. 92. 
Asumsi dasar ekonomi makro melewati gejolak yang digerakkan oleh sejumlah aspek dengan penjelasan lebih rinci sebagai berikut, dalam ceteris paribus: 1) Pertumbuhan ekonomi memberi pengaruh terhadap pendapatan negara. Kegiatan ekonomi yang berputar lebih cepat membawa pengaruh pada penerimaan perpajakan, antara lain Pajak Pertambahan Nilai (PPN), pajak perdagangan Internasional, dan juga Pajak Penghasilan, baik badan usaha maupun orang pribadi, serta cukai; 2) Laju inflasi yang meningkat memberi pengaruh terhadap pendapatan negara bersumber pada $\mathrm{PPh}$ nonmigas, PBB, PPN, serta pajak lainnya; 3) Pergerakan nilai tukar mata uang rupiah terhadap nilai dolar Amerika Serikat memberi pengaruh terhadap aspek pendapatan $\mathrm{PPh}$ minyak dan gas, serta penerimaan pajak dari aktivitas perdagangan internasional. ${ }^{15}$

Artikulasi dari penerimaan pajak sepanjang rentang waktu tersebut bersumber dari: 1) peningkatan restitusi dengan angka $21,11 \%$;2) moderasi harga komoditas di pasar global yang berakibat menurunnya pertumbuhan pendapatan aktivitas pertambangan dan bisnis sawit yang terkontraksi; 3) normalisasi kegiatan impor; serta 4) ekspansi sektor manufaktur dalam pergerakan yang terbatas (terlihat dari angka Penamana Modal di Indonesia (PMI) 49,5 di bulan Desember). ${ }^{16}$

Penerimaan pajak pada periode bulan Januari hingga September 2020 menunjukkan grafik yang fluktuatif. Terhitung sejak bulan Januari hingga September 2020, Direktorat Jenderal Pajak Republik Indonesia (DJP RI) mampu mengumpulkan pajak sebesar Rp 750,62 triliun atau hanya mampu menghimpun penerimaan pajak sebesar $62,62 \%$ dari target pencapaian pajak menurut Peraturan Presiden No. 72 Tahun 2020. Realitas penerimaan pajak periode Januari hingga September 2020 ini mengalami kontraksi, jika dilakukan komparasi dengan pendapatan pajak pada rentang waktu yang sama pada tahun 2019. ${ }^{17}$

\footnotetext{
15 loc.cit.

${ }^{16}$ op.cit., h. 94.
}

${ }^{17}$ Sumber data diperoleh dari Center for Indonesia Taxation Analysis (CITA) dan diolah dari Laporan Kinerja Direktorat Jenderal Pajak Republik Indonesia (LAKIP) 2019.
Tabel 1. Kinerja Per Jenis Pajak Januari - September 2020

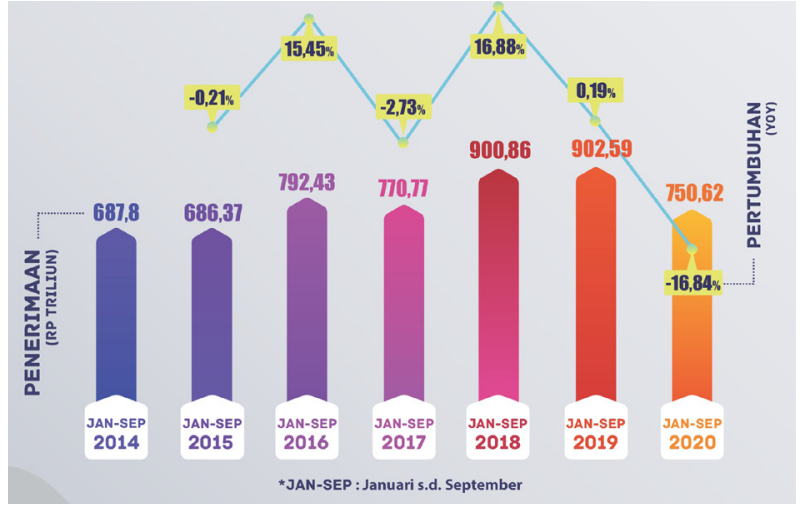

Infografik dan Sumber data: Disalin dari Center for Indonesia Taxation Analysis (CITA)

Pada saat kondisi negara dalam keadaan normal, salah satu sumber utama untuk membiayai berbagai kebutuhan bantuan dan subsidi bagi masyarakat dan entitas bisnis yang terdampak pandemi Covid-19 diperoleh dari sumber kekayaan negara dan dana yang dikumpulkan dari pajak-pajak yang dipungut dari masyarakat. Namun, dalam keadaan yang tidak normal atau tidak biasa (extra ordinary condition) seperti wabah pandemi global Covid-19 saat ini, pemerintah memerlukan pengaturan yang bersifat tersendiri dalam penyelenggaraan pemerintahan, termasuk dalam hal kebijakan fiskal dan perpajakan untuk tetap dapat mendukung sumber pembiayaan negara tanpa membebani masyarakat yang terdampak wabah pandemi, sehingga fungsi-fungsi negara mampu tetap beroperasi secara efektif.

Penyelenggaraan pelayanan publik yang menjamin keamanan, kesehatan, dan keselamatan jiwa setiap warga negara dilakukan Pemerintah dengan berdasarkan sistem norma hukum yang diperuntukkan bagi keadaan negara tidak normal (extra ordinary condition). ${ }^{18}$

Ditetapkannya Peraturan Pemerintah Pengganti Undang-Undang No. 1 Tahun 2020 tentang Kebijakan Keuangan Negara dan Stabilitas Sistem Keuangan untuk Penanganan Pandemi Corona Virus Disease 2019 (Covid-19) dan/atau Dalam Rangka Menghadapi Ancaman yang Membahayakan Perekonomian Nasional dan/atau Stabilitas Sistem Keuangan menjadi UU No. 2 Tahun 2020 oleh

18 Kim Lane Scheppele. (2004). "Law in a Time of Emergency: States of Exeption an the Temptations of 9/11". HeinOnline-U.Pa. Journal of Constitutional Law. Vol. 6:5, 20032004, p. 104 
DPR, merupakan landasan hukum bagi pemerintah untuk memperoleh otoritas dalam pengelolaan dan penggunaan APBN dengan perubahan alokasi anggaran yang diproritaskan untuk bidang kesehatan, penyelamatan fiskal dan ekonomi nasional akibat pandemi Covid-19.

Melalui undang-undang ini, Pemerintah mengupayakan prioritas utama untuk pengamanan kualitas kesehatan dan stabilitas perekonomian nasional, melalui perhatian penuh pada belanja sektor kesehatan, jaring pengaman sosial (social safety net), dan juga pemulihan perekonomian secara menyeluruh, termasuk juga sektor dunia usaha maupun masyarakat yang mengalami dampak negatif dari pandemi Covid-19, dengan mengalokasikan anggaran hingga Rp 203,9 triliun untuk perlindungan sosial. Nilai tersebut setara 35\% dari total Anggaran Program Pemulihan Ekonomi Nasional.

Untuk mengantisipasi dampak yang timbul akibat pandemi Covid-19, Pemerintah juga telah menetapkan kebijakan untuk memberikan dukungan dengan pemberian insentif relaksasi perpajakan serta bantuan kepada UMKM (melebihi jumlah 60 juta) dengan berbagai format, antara lain subsidi bunga pinjaman dan penundaan angsuran, serta bantuan tambahan modal kerja. Masih dalam rangkaian program Pemulihan Ekonomi Nasional, pemerintah juga menetapkan kebijakan untuk pelaku usaha di sektor riil dan sektor keuangan yang meliputi usaha besar, menengah, kecil, sampai mikro, dan juga koperasi yang aktivitas bidang usahanya mengalami dampak negatif dari pandemi Covid-19. Alokasi dana Rp 123,46 triliun digunakan untuk memberi dukungan kepada UMKM. Alokasi anggaran untuk UMKM ini mencapai 21\% dari seluruh Anggaran Pemulihan Nasional yang dialokasikan oleh Pemerintah. ${ }^{19}$

Pemerintah juga memberikan insentif usaha di berbagai sektor yang terdampak pandemi sebanyak Rp 120,61 triliun, yang berarti mencapai 20\% dari seluruh Anggaran Program Pemulihan Ekonomi Nasional yang sudah ditetapkan pemerintah. Untuk mendukung pembiayaan korporasi, Pemerintah juga telah menggelontorkan alokasi dana sebesar Rp 44,57 triliun, angka ini merupakan $8 \%$ dari seluruh Anggaran Program Pemulihan Ekonomi Nasional. Pada bidang sektoral dan pemrintah daerah,

\footnotetext{
${ }^{19}$ Direktorat Jenderal Pajak RI. (2020). Laporan Kinerja Direktorat Jenderal Pajak RI Tahun 2020, h. 37.
}

Grafik 1.

Anggaran Program Pemulihan Ekonomi Nasional (PEN) Berdasarkan Fungsi

- Perlindungan sosial
- Insentif usaha
= UMKM
- Pembiayaan korporasi
- Sektoral dan Pemda

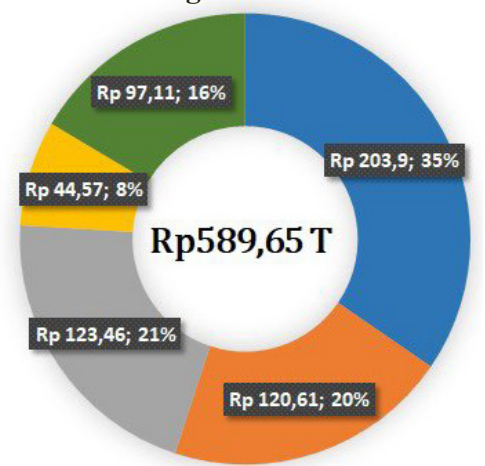

Sumber Data: Kementerian Keuangan Republik Indonesia

Pemerintah Pusat menetapkan alokasi sebanyak $16 \%$ dari Anggaran Program Pemulihan Ekonomi Nasional, yaitu berjumlah 97,11 triliun Rupiah. ${ }^{20}$

Pada bidang perpajakan, Pemerintah mengalokasikan dana stimulus dan relaksasi fiskal yang diharapkan mampu memberi manfaat yang dapat dinikmati oleh masyarakat secara langsung, tenaga medis, serta para pelaku usaha baik di sektor riil maupun sektor keuangan yang meliputi usaha berskala mikro, kecil, menengah, dan besar, serta koperasi secara lebih merata. Sebagai bentuk antisipasi terhadap ancaman resesi yang timbul akibat pandemi Covid-19, Pemerintah menetapkan kebijakan perpajakan yang mendukung bagi terwujudnya kebijakan fiskal yang kondusif bagi pemulihan ekonomi nasional. Pemerintah membuat kebijakan relaksasi perpajakan, berupa insentif dan pajak yang ditanggung Pemerintah (P-DTP), pemungutan, dan penagihan pajak. ${ }^{21}$

Berdasakan PMK No. 23/PMK. 03/2020 tentang Insentif Pajak untuk Wajib Pajak Terdampak Wabah Virus Corona dan PMK No. 44/PMK.03/2020 Tahun 2020 tentang Insentif Pajak untuk Wajib Pajak Terdampak Pandemi Corona Virus Disease 2019 yang substansinya secara eksplisit mengatur pengecualian dari ketentuan mengenai kewajiban wajib pajak PPh 21 ditanggung pemerintah bagi 1062 KLU/perusahaan KITE/penyelenggara/pengusaha kawasan berikat/PDKB, Pembebasan PPh 22 impor kepada $431 \mathrm{KLU} /$ perusahaan KITE/penyelenggara/ pengusaha kawasan berikat/PDKB, Pengurangan angsuran PPh 25 sebesar 30\% kepada 846 KLU/

\footnotetext{
${ }^{20}$ loc.cit.

${ }^{21}$ Sumber data diperoleh dari Center for Indonesia Taxation Analysis (CITA).
} 
perusahaan KITE/penyelenggara/pengusaha kawasan berikat/PDKB, dan Percepatan restitusi PPN bagi 431 $\mathrm{KLU} /$ perusahaan KITE/penyelenggara/pengusaha kawasan berikat/PDKB restitusinya paling banyak Rp5 miliar.

Dengan berdasarkan Undang-Undang No. 2 Tahun 2020 tentang Penetapan Peraturan Pemerintah Pengganti Undang-Undang Nomor 1 Tahun 2020, ${ }^{22}$ menjadi UU No. 2 Tahun 2020 oleh DPR, Pemerintah melalui berbagai bauran Peraturan Menteri Keuangan menetapkan dan menggunakan diskresi kewenangannya memberikan insentif perpajakan bagi masyarakat terdampak pandemi Covid-19, yang meliputi: 1) Insentif $\mathrm{PPh}$ Pasal 21;2) Insentif $\mathrm{PPh}$ Pasal 22 Impor; 3) Insentif angsuran PPh Pasal 25; 4) insentif PPN; dan 5) Insentif Pajak untuk UMKM.

Regulasi perpajakan merupakan sistem yang disusun untuk membantu memenuhi kebutuhan negara dan masyarakat sebagai para aktor dalam mengalokasikan serta mendistribusikan kesejahteraan kepada segenap anggota masyarakat. Dalam konteks penyelenggaraan kesejahteraan umum, kewenangan pemungutan dan penagihan pajak oleh negara secara mendasar merupakan fungsi esensial sebagai motor untuk menggerakkan roda pembangunan dan fungsi jasa, sekaligus juga fungsi niaga. Pembuatan produk hukum berupa undang-undang dan kebijakan mengenai pajak oleh penyelenggara negara harus bisa menjadi instrumen alokasi dan distribusi pajak pada seluruh lapisan masyarakat, sehingga merupakan refleksi pembagian beban pajak yang merata dan adil. $^{23}$

Penggunaan instrumen yuridis untuk penagihan dan penegakan hukum pajak yang diberikan oleh undang-undang kepada Pemerintah merupakan sarana

22 Undang-undang yang dimaksud adalah Peraturan Pemerintah Pengganti Undang-Undang (PERPPU No. 1 Tahun 2020 tentang Kebijakan Keuangan Negara dan Stabilitas Sistem Keuangan untuk Penanganan Pandemi Corona Virus Disease 2019 (Covid-19) dan/atau Dalam Rangka Menghadapi Ancaman yang Membahayakan Perekonomian Nasional dan/atau Stabilitas Sistem Keuangan, yang kemudian disetujui oleh DPR menjadi UU No. 2 Tahun 2020 tentang Penetapan Peraturan Pemerintah Pengganti Undang-Undang Nomor 1 Tahun 2020, menjadi UU No. 2 Tahun 2020 oleh DPR, merupakan landasan hukum bagi Pemerintah untuk memperoleh otoritas dalam pengelolaan dan penggunaan APBN dengan perubahan alokasi anggaran yang diproritaskan untuk bidang kesehatan, penyelamatan fiskal dan ekonomi nasional akibat pandemi Covid-19.

${ }^{23}$ Eugene F. Miller. (2010). Hayek's The Constitution of Liberty. London: The Institute of Economic Affairs, h. 78. bagi berlakunya hukum positif di masyarakat. Dalam konteks negara sebagai sistem sosial, kewenangan lembaga pelaksana regulasi bidang perpajakan, adalah bahasa terstruktur atau suatu simbol sebagai prasyarat agar mampu menjadi instrumen dengan kapabilitas mengalokasikan serta mendistribusikan kekayaan atau kemampuan ekonomi individu (warga masyarakat) agar menjangkau seluruh lapisan masyarakat.

Peran utama kebijakan perpajakan yang dibuat oleh pemerintah adalah untuk mengalokasikan setiap dana yang bersumber dari sektor pajak demi kesejahteraan masyarakat. Kebijakan pemerintah ini sebagai perwujudan usaha pencapaian tujuan konkret sehari-hari yang bersifat dinamis. ${ }^{24}$ Kebijakan tersebut juga merupakan bentuk tugas administrasi, dengan tujuan untuk mengarahkan serta mengalokasikan ketersediaan sumber daya guna mencukupi dinamika kebutuhan masyarakat agar tercipta kesejahteraan umum. Dari kebijakan perpajakan yang ditetapkan pemerintah harus dapat menjadi gambaran atas keputusan negara berkaitan tentang hal-hal apa saja yang harus dibayarkan oleh individu serta manfaat apa yang akan diterima secara kolektif, yang merefleksikan terciptanya kesejahteraan umum (bonum publicum), yaitu melalui mekanisme penentuan beban pajak menurut kapasitas serta kemampuan warga masyarakat. ${ }^{25}$

\section{PENUTUP}

\section{Kesimpulan}

Berdasarkan hasil studi dan analisis yang telah dilakukan pada penelitian ini, maka diperoleh simpulan sebagai berikut:

${ }^{24}$ Pemerintah, melalui Kementeriaan Keuangan RI, telah menetapkan regulasi sebagai dasar legitimasi berbagai kebijakan yang ditujukan untuk penguatan fiskal dan penyelenggaraan ekonomi masyarakat yang terdampak pandemi Covid-19. Berdasarkan Undang-undang Perpajakan, khususnya UndangUndang No. 6 Tahun 1983 tentang Ketentuan Umum dan Tata Cara Perpajakan sebagaimana telah beberapa kali diubah, yang dengan Undang-Undang No. 16 Tahun 2009 dan Undang-Undang No. 19 Tahun 1997 tentang Penagihan Pajak dengan Surat Paksa sebagaimana telah diubah dengan Undang-Undang No. 19 Tahun 2000 Penagihan Pajak dengan Surat Paksa, Pemerintah juga telah diberi kewenangan dan diskresi untuk melakukan penegakan hukum pajak dengan berbagai instrumen yuridis.

25 J. Raz. (1994). Ethic in Public Domain, Essays in The Morality of Law and Politics. London: Oxford University Press, h. 73 . 
1. Berbagai bauran kebijakan Pemerintah berupa berbagai produk hukum Peraturan Menteri Keuangan di bidang perpajakan yang pelaksaannnya dilakukan oleh Pemerintah Direktorat Jenderal Pajak, merupakan bentuk penggunaan diskresi kewenangan (discretion of power) dalam pemungutan dan penagihan pajak, pada dasarnya digunakan berdasarkan pada pertimbangan manfaat dan kegunaan yang sebesar-besarnya bagi kepentingan masyarakat, bertujuan untuk mengoptimalisasi dalam menangani pandemi Covid-19 serta menjaga kesinambungan perekonomian serta untuk tujuan menyelamatkan penerimaan negara dari sektor pajak, dengan tetap tunduk pada aturan dan atau norma hukum positif sebagai landasan hukumnya.

2. Pemungutan dan penagihan pajak dengan menggunakan diskresi kewenangan (discretion of power) yang dilakukan oleh Pemerintah pada masa pandemi Covid-19, diantaranya digunakan untuk memfasilitasi program perlindungan sosial dan kesehatan masyarakat, mengalokasikan dana stimulus dan relaksasi fiskal secara lebih merata, yang manfaatnya dapat dinikmati oleh segenap masyarakat, tenaga kesehatan, serta para pelaku usaha di sektor riil maupun sektor keuangan di semua lini usaha mikro, kecil, menengah, besar, dan juga koperasi yang kegiatan usahanya terdampak oleh Covid-19.

\section{Rekomendasi}

Berdasarkan penelitian dan hasil analisis permasalahan, maka rekomendasi penelitian ini adalah:

1. Pemerintah melalui Direktorat Jenderal Pajak RI perlu mempertimbangkan ekstensifikasi dan intensifikasi subyek dan obyek pajak untuk tetap dapat memungut pajak kepada masyarakat yang masih mempunyai kemampuan dalam membayar pajak bedasarkan prinsip ability to pay.

2. Pemerintah perlu mempertimbangkan berbagai kebijakan insentif pajak dan memfasilitasi kemudahan administrasi perpajakan serta kebijakan pengenaan tarif pajak yang kompetitif bagi investor yang bersedia menanamkan modalnya di sektor-sektor padat karya dan mendukung pertumbuhan iklim ekonomi.

\section{DAFTAR PUSTAKA}

\section{Peraturan Perundang-undangan:}

Undang-Undang Nomor 19 Tahun 1997 tentang Penagihan Pajak dengan Surat Paksa.

Undang-Undang Nomor 19 Tahun 2000 tentang Perubahan atas Undang-Undang Nomor 19 Tahun 1997 tentang Penagihan Pajak dengan Surat Paksa.

Undang-Undang Nomor 28 Tahun 2007 Perubahan Ketiga Atas Undang-Undang Nomor 6 Tahun 1983 tentang Ketentuan Umum dan Tata Cara Perpajakan.

Peraturan Pemerintah Pengganti Undang-Undang No. 1 Tahun 2020 tentang Kebijakan Keuangan Negara dan Stabilitas Sistem Keuangan untuk Penanganan Pandemi Corona Virus Disease 2019 (Covid-19) dan/atau Dalam Rangka Menghadapi Ancaman yang Membahayakan Perekonomian Nasional dan/atau Stabilitas Sistem Keuangan.

Peraturan Menteri Keuangan Republik Indonesia Nomor 19/PMK.07/2020 Penyaluran dan Penggunaan DBH, DAU, dan Dana Insentif Daerah Tahun Anggaran 2020 dalam Rangka Penanggulangan Corona Virus Disease 2019 (COVID-19).

Peraturan Menteri Keuangan Republik Indonesia Nomor 23/PMK. 03/2020 tentang Insentif Pajak Untuk Wajib Pajak Terdampak Wabah Virus Corona.

Peraturan Menteri Keuangan Republik Indonesia Nomor 28/PMK.03/2020 Pemberian Fasilitas Pajak Terhadap Barang dan Jasa Yang Diperlukan Dalam Rangka Penanganan Pandemi.

Peraturan Menteri Keuangan Republik Indonesia Nomor 34/PMK.04/2020 tentang Relaksasi Ketentuan Impor Alat Kesehatan Untuk Keperluan Penanganan COVID-19.

Peraturan Menteri Keuangan Republik Indonesia Nomor 44/PMK.03/2020 tentang Insentif Pajak untuk Wajib Pajak Terdampak Pandemi Corona Virus Disease 2019.

\section{Buku:}

E. Sumaryono. (2020). Etika dan Hukum, Relevansi Teori Hukum Kodrat Thomas Aquinas. Yogyakarta: Penerbit Kanisius. 
Eugene F. Miller. (2010). Hayek's The Constitution of Liberty. London: The Institute of Economic Affairs.

Frans Magnis Soeseno. (2006). Etika Politik, PrinsipPrinsip Moral Dasar Kenegaraan Modern. Jakarta: Pustaka Gramedia.

Hari Chand. (1994). Modern Jurisprudenc. Kuala Lumpur: International Law Book Series.

J. Raz. (1994). Ethic in Public Domain, Essays in The Morality of Law and Politics. London: Oxford University Press.

Soetandyo Wignjosoebroto. (2002). Hukum, Paradigma, Metode, dan Dinamika Masalahnya, Jakarta: Penerbit Elsam.

Sonny Keraf. (2016). Pasar Bebas, Keadilan, dan Peran Pemerintah. Yogyakarta: Penerbit Kanisius.

\section{Jurnal:}

Kim Lane Scheppele. (2004). "Law in a Time of Emergency: States of Exeption an the Temptations of 9/11". HeinOnline-U.Pa. Journal of Constitutional Law. Vol. 6:5, 2003-2004, p. 104.

\section{Artikel Orasi Ilmiah:}

Sjachran Basah. (1986). Perlindungan Hukum terhadap Sikap Tindak Administrasi Negara. Orasi Dies Natalis XXIX Unpad tgl. 24 September 1986.

\section{Laporan:}

Direktorat Jenderal Pajak RI. (2020). Laporan Kinerja Direktorat Jenderal Pajak RI Tahun 2020.

Direktorat Potensi dan Sistem Perpajakan Direktorat Jenderal Pajak RI dan Data Asian Development Bank (ADB). (2017). Key Indicators of Developing Asian and Pacific Countries.

Laporan Kinerja Direktorat Jenderal Pajak Republik Indonesia (LAKIN DJP RI 2019).

\section{Surat Kabar:}

Harian Kompas, 21 Maret 2020 dan Laporan Kementerian Keuangan Republik Indonesia dalam Rapat Dengar Pendapat dengan Dewan Perwakilan Rakyat Republik Indonesia pada tanggal 20 Maret 2020. 